\title{
1. Mapping critical habitat of waterbirds 2 in the Arctic for risk management in s respect of IFC PS6
}

4

5

6

7

8

9

\section{AUTHORS}

Lammert Hilarides ${ }^{1 *}$, Tom Langendoen ${ }^{1}$, Stephan Flink ${ }^{1}$, Merijn van Leeuwen ${ }^{1}$, Bart Steen, Alexander V. Kondratyev ${ }^{2}$, Andrea Kölzsch ${ }^{3,4}$, Tomas Aarvak ${ }^{5}$, Helmut Kruckenberg ${ }^{6}$, Didier Vangeluwe ${ }^{7}$, Emil Todorov $^{8}$, Anne Harrison ${ }^{9}$, Eileen Rees ${ }^{10}$, Adriaan M. Dokter ${ }^{11}$ Bart Nolet $^{12}$ and Taej Mundkur ${ }^{1}$

\section{AFFILIATIONS}

${ }^{1}$ Wetlands International, P.O. Box 4716700 AL Wageningen, The Netherlands

\section{${ }^{2}$ Affiliation Kondratyev}

${ }^{3}$ Max Planck Institute for Ornithology, Radolfzell, Germany

${ }^{4}$ University of Konstanz, Konstanz, Germany

${ }^{5}$ Norwegian Ornithological Society

${ }^{6}$ Institute for Wetlands and Waterbird Research (IWWR) e.V., Germany, Am Steigbügel 3, D-27283

Verden (Aller), Germany

ADDRESSES

lammert.hilarides@wetlands.org

1․ $\underline{1}$.langendoen@wetlands.org, stephan.flink@wetlands.org, merijn.vanleeuwen@wetlands.org,

b.r.l.steen2@gmail.com, taej.mundkur@wetlands.org,

akondratyev@mail.ru, akoelzsch@orn.mpg.de, 
21 helmut.kruckenberg@blessgans.de, rozenfeldbro@mail.ru, Didier.Vangeluwe@naturalsciences.be,

22 emil.georgiev.todorov@gmail.com, anne.harrison@wwt.org.uk, eileen.rees@wwt.org.uk,

23 a.Dokter@nioo.knaw.nl, B.Nolet@nioo.knaw.nl

24

Mapping Arctic waterbird critical habitat

27

28

29

30

31

32

33

34

35

36

Number of references: \#

Number of tables: \#

Number of figures: \#

- Summary (533 words)

- Main text (\# words)

- Acknowledgements (\# words)

- References (\# words)

- Table and figure legends (\# words)

37 


\section{SUMMARY}

1. Economic development and energy exploration are increasing in the Arctic. Important breeding habitats for many waterbird species, which have previously been relatively undisturbed, are now being subjected to these anthropogenic pressures. The conservation of the habitats and the species they support is a significant challenge for sustainable development. Even if governments and corporates operating in this fragile environment are committed to sustainable development, there is little information available to avoid, mitigate and manage environmental risk and impacts. Taking a risk management perspective, we followed the International Finance Corporations' (IFC) Performance Standard 6 (PS6) criteria on Environmental and Social Sustainability and developed an approach to identify "critical habitat", as defined in IFC PS6, for waterbird species breeding in the Arctic. While the range of these waterbirds is roughly known, more accuracy is needed for proper risk assessment.

2. We have therefore gone a step further by modelling suitable habitat within these ranges. Depending on the relevance of the species for IFC PS6 and the level of certainty we separated the classes likely and potential critical habitat. We tested the approach for Russian breeding populations of five Anatidae species (White-fronted Goose Anser albifrons, Lesser White-fronted Goose Anser erythropus, Brent Goose Branta bernicla, Redbreasted Goose Branta ruficollis and Bewick's Swan Cygnus columbianus bewicki). Likely critical habitats were identified through a review of literature and available data for these waterbird species and multi-species congregations. To address the information gap for most of the Russian Arctic a species distribution modelling approach was used. The outputs of this approach were labelled as potential critical habitat, indicating the lower level of certainty than likely critical habitat.

3. Based on existing information the amount of likely critical habitat is estimated to be at least $X, X X X, X X X \mathrm{~km}^{2}$. For the five Anatidae species, $X, X X X, X X X \mathrm{~km}^{2}$ potential critical habitat was 
identified; $95 \%$ of these areas were outside of the area boundaries of likely critical habitat for the species.

4. Insufficient data in the east of the study area did affect the results, as some areas known to support breeding populations were not identified as suitable. Conversely, species' distributions may be overpredicted in other areas; It should also be recognized that the analyzed species currently have depressed populations and may therefore only utilize a proportion of suitable habitat available.

5. For risk assessment purposes however, it is better to predict false positives, rather than false negatives. The study indicates that there are large areas in the Arctic that are potentially important for each of the Anatidae species modelled, but are not yet recognised as key important areas. The results confirm that there is still much to learn about waterbird distribution and abundance in the Russian Arctic.

6. Synthesis and applications The critical habitat maps produced do not just provide a new source of information for the economic development sector, but provide it in a way that is relevant to the sector and directly applicable. The maps are useful for initial risk assessments of potential developments, to identify likely impacts and to consider mitigation options, in accordance with IFC PS6. Risk assessors should exercise caution and detailed surveys for any development in areas predicted to be suitable for each species should be carried out.

\section{KEYWORDS}

Species distribution models; International Finance Corporation; Performance standards; Risk assessment. 
84

\section{INTRODUCTION}

The Arctic provides important breeding habitat for many waterbird species that occur in Europe and Africa (Wohl 2006). Until recently, the breeding habitats have been relatively undisturbed, with low human densities, especially in comparison to other parts of the waterbird species' flyways, where they compete with humans and many of their habitats have been modified or lost. However, with economic development, and oil and gas exploration, the Arctic is being subjected to increasing anthropogenic pressures that pose significant challenges for the management and conservation of Arctic habitats and the species they support (Wohl 2006).

The International Finance Corporation (IFC) is a member of the World Bank Group that focuses on private sector development and has a strategic commitment to sustainable development. For this, the IFC has developed eight performance standards on social and environmental sustainability; approximately 80 large corporates in the primary resource and financing sectors have adopted these standards. Of relevance to the protection of habitats and waterbirds in the Arctic, Performance Standard 6 (PS6) deals with "Biodiversity conservation and sustainable management of living natural resources" (IFC 2012a). In accordance with IFC PS6 different risk management approaches are employed to protect biodiversity and ecosystem services based on the sensitivity and values of a habitat. Thus, the identification of important habitats for waterbirds is a crucial step to inform management plans and minimise the impacts of human activities.

PS6 gives a definition of "critical habitat" and provides guidance on how to act when operating in or close to a critical habitat (IFC 2012b). Critical habitat is a geographic area important for biodiversity and may include: (1) habitats of significant importance to Critically Endangered and/or Endangered species (as categorized in the IUCN Red List of Threatened Species; IUCN 2015); (2) habitats of significant importance to endemic and/or restricted range species; (3) habitats that support globally significant concentrations of migratory species and/or congregatory species; (4) highly threatened and/or unique ecosystems; and/or (5) areas associated with key evolutionary processes (IFC 2012a). 
If an area contains critical habitat, IFC PS6 requires a Biodiversity Action Plan to be developed and implemented (IFC 2012a). However, business developers rely on existing species distribution, biodiversity and protected areas data sets, because there is no global map of critical habitat. While some of the existing data sets are good indicators of critical habitat and use criteria that overlap with those used by the IFC (Martin et al. 2015), the data are generally incomplete or require interpretation under the IFC guidelines. As a result, there are many areas of critical habitat for species, ecosystems and evolutionary processes that have not yet been identified, particularly in the Arctic. Only few robust, long-term monitoring programmes are in action or openly available here, even for waterbirds, one of the most intensely studied animal groups in the world.

In this study, we propose a new methodology to identify critical waterbird habitat in the Arctic, based on PS6 criteria. We focused on areas covered by both the Conservation of Arctic Flora and Fauna (CAFF) working group and the African Eurasian Waterbird Agreement (AEWA). Given the

121 limited data availability and geographic gaps in information, we adopted a modelling approach. The

122 model outputs are translated into maps that detail potential and likely areas of IFC PS6 critical

123 habitat in the Arctic. These maps can improve conservation by supporting risk assessments for

124 potential developments, identify likely impacts and consider mitigation options. 


\section{MATERIALS AND METHODS}

126

127

\section{Species selection}

We analysed five Anatidae species: White-fronted Goose Anser albifrons, Lesser White-fronted

Goose Anser erythropus, Brent Goose Branta bernicla, Redbreasted Goose Branta ruficollis and

Bewick's Swan Cygnus columbianus bewicki. These all have populations that breed exclusively in the

Russian Arctic and were considered likely to trigger criteria 1 or 3 of PS6, based on their red list status or occurrence in large enough concentrations, respectively.

\section{Model}

To produce detailed species distribution maps that could serve as a basis for critical habitat maps we used MaxEnt (Phillips, Dudík \& Schapire 2004). The maps output by the model predict the suitability of habitat in the study area. The model has been used widely in the scientific community for a variety of species across a wide spectrum of habitats (Elith et al. 2006; Phillips \& Dudik 2008; Edrén et al. 2010).

\section{Species occurrence}

Species occurrence samples were obtained from online databases, telemetric studies, regional surveys and literature sources. To exclude data on vagrant birds, or otherwise unrepresentative data, only samples from within the known range of a species were used. The large distances migratory waterbirds cover during migration means that they use very different habitats during different life cycle stages, including breeding, moulting, migration and wintering. Combining these life cycle stages into a single model would lead to an overprediction of suitable habitats. The data were therefore filtered by date and location, specific for each species, so that only the breeding season samples remained (see Fig. S1 in Supporting Information). Breeding season samples may include moulting for some species, when moulting happens at the same location. As such, samples were principally categorized as breeding or breeding/moulting. 
Especially when using samples from online databases, such as the Global Biodiversity Information

Telemetry data: while telemetry data provide occurrence samples that represent true and relatively accurate occurrences of individuals, these data may not be representative of the full population because of the limited number of individuals equipped with transmitters. By design, these samples are also highly autocorrelated; that is, every successive sample is inherently close to the preceding sample, both in time and space. Since MaxEnt assumes a random distribution of occurrence samples, of the potentially unrepresentative telemetry-based samples.

Environmental predictors were selected that would potentially influence the species' distributions, were available and were of consistent quality across the entire study area. Selected environmental predictors included bio-climatic variables, distances to different types of waterbodies, elevation, soilrelated variables and land cover data (see Table S1 in Supporting Information). To prevent distortion of the model by decreasing raster cell size at higher latitudes (Elith et al. 2011), all predictors were 
173

174

175

176

177

178

Although many environmental predictors were readily available from the literature or online databases, some environmental predictors, expected to be of ecological significance to each of the species, were produced (distances to coast, freshwater, estuary and shallow coastal flats, slope, terrain roughness and dominant soil type; see below). Because of the different sources of data, the exact extent (generally the coastline), of each produced environmental predictor was not consistent, so the extent of the bio-climatic variables was used as a reference.

Distance to coast: This predictor was created by measuring the "Euclidian distance" to sea, using a bioclim predictor as reference for the coastline.

Distance to freshwater: this was based on the 250 m MODIS Water Mask data set (Carroll et al. 2009) with the sea masked out using the "no data" zone of a bioclim predictor. The "Euclidian distance" tool was used to calculate the distance between each cell in the study area and the nearest cell with freshwater.

Distance to estuary: although there is a Global Estuary Database (Alder 2003), this was considered too coarse, with many medium to small estuaries omitted. Therefore, the lowest sub-basin polygon was selected from the HydroBASINS level 10 data set (Lehner \& Grill 2013), for each basin larger than $500 \mathrm{~km}^{2}$. This minimum basin size threshold was set to avoid the selection of every coastal polygon. The "Euclidian distance" was then calculated between each cell in the study area and the nearest estuary.

Distance to shallow coastal flats: shallow coastal flats function as feeding grounds for many waders, (sea-) ducks and geese. The International Bathymetric Chart of the Arctic Ocean (Jakobsson et al. 2012) was used and the shallow areas at sea (experimentally determined between $+1 \mathrm{~m}$ and $-1 \mathrm{~m}$ ) were selected. Within these shallow areas a sub-selection was made of all the areas that had a slope less than 0,002. From this subset only areas of at least $10 \mathrm{~km}^{2}$ were selected. The "Euclidian distance" tool was used to calculate the distance between each cell in the study area and the nearest shallow coastal flat. 
Slope: this was calculated from the BIOCLIM digital elevation model.

199

200

201

202

203

204

205

206

207

208

209

210

211

212

213

214

Terrain roughness: the standard deviation predictor of the 30 arc-seconds USGS Global Multiresolution Terrain Elevation Data (GMTED2010) (Danielson \& Gesch 2011) was used as a proxy for terrain roughness. A "rough" area has large fluctuations in height and therefore a large standard deviation of elevation, whereas flat areas have a low standard deviation.

Dominant Soil Type: this predictor was based on the International Soil Reference and Information Centre's $1 \mathrm{~km}$ soilgrid data set (Hengl et al. 2014). Unfortunately, this predictor had data gaps for areas covered with seawater and freshwater, as well as permanent snow and ice cover. These gaps were partially filled using freshwater pixels from 250m MODIS Water Mask.

\section{Correlation analysis}

Although MaxEnt is relatively robust to correlated predictors (Elith et al. 2011), removing them does tend to improve the model (Elith \& Leathwick 2009). Therefore, $R$ was used to conduct pairwise assessments of the correlations between the environmental predictors (Table S2). Because not all predictors had a normal distribution, Spearman's rank correlation coefficients between each possible combination of predictors based on 100,000 random locations were calculated.

\section{Test model runs}

Test models were run using the quality assessed and spatially filtered occurrence samples and all environmental predictors, to identify the most important predictors for each species model (Table S1). Predictors were ranked by their permutation importance, as an indication of unique information, and percent contribution. The highly correlated predictors, with Spearman rho values below -0.75 or above 0.75 were removed (Table S2); this meant the predictors with the highest permutation importance were retained. 


\section{Model runs}

MaxEnt was run with the selected environmental predictors and the following settings changed from their default: (1) 10 replicates; (2) bootstrap sampling; (3) random seed; (4) 30\% random test percentage; (5) response curves; (6) jackknife procedure; (7) maximum iterations were set at 2000 and 8) write background predictions.

\section{Suitable habitat}

One output of MaxEnt for each model run was a map, showing the average probability (of the 10 replicates) of habitat suitability for each species within each raster cell; that is, a logistic value between 0 (not suitable) and 1 (very suitable) (Fig. S1). A threshold was applied to these probability maps for each species to create binary suitable/unsuitable habitat maps. The threshold was calculated using the "equal training sensitivity and specificity" method in MaxEnt, to provide a balance between the omission and commission errors.

\section{Critical habitat}

This study applied the criteria from the IFC PS6 Guidance Notes using a rules based approach (Table 1) to classify critical habitat from the maps showing suitable habitats. These rules were derived from IFC PS6 criteria 1 and 3. In areas other than the Arctic, or for species groups other than waterbirds, criterion 2 (on endemic or restricted range species) might also be applicable.

The classification for critical habitat followed that of Martin (Martin et al. 2015) and distinguished between "potential" and "likely" critical habitat, based on relevance and certainty, indicating the difference between modelled critical habitat and that confirmed by literature or other sources.

Likely critical habitat: Independently from the modelling study, for each species and life cycle stage, areas that would qualify as critical habitat under IFC PS6 were identified through a review of the literature (Krivenko 2000);(Ramsar Convention);(Arctic and Antarctic Research Institute), from IBA information (Birdlife International) and from the Critical Site Network Tool (Wings Over Wetlands 
2011). Under PS6 criteria an area qualifies as critical habitat if it regularly supports $1 \%$ of a migratory species' population. The areas known to support $>1 \%$ of a population were therefore classified as "likely critical habitat" and also served as input data for the next step, in which the threshold value for "potential critical habitat" was determined.

Potential critical habitat: The threshold value used to identify the "suitable habitat" for a species (see above) was based on statistical, rather than ecological, considerations. The "suitable habitat" had quite a large range of probability values; that is, from 0.16 for the "least probable suitable habitat" to 0.92 for the "most probable suitable habitat". To parameterize IFC PS6 criterion 3 and identify "potential critical habitat", the habitat that was suitable enough as well as large enough to support congregations of $>1 \%$ of a species' population was identified; that is, habitat that was (1) more suitable than the average habitat suitability of known key areas; and (2) larger than the typical size of known key areas was identified. For this, the key areas identified as likely critical habitat were overlaid with the probability map and then: (1) the average probability value of the suitable habitat within the key areas was calculated; and (2) the median size of the suitable habitat within the key areas was calculated. For (2), the median was preferred over the average, because of the small sample size and to minimize the effect of extreme values. The raster was then resampled from the original 1-km resolution grid, using the square root of the median of the suitable habitat area in the known key areas, to identify suitable habitat of sufficient size. The average probability value calculated in step (1) was then used as the threshold to identify the potential critical habitat on the resampled raster. Thus, the resulting maps identified habitats with a relatively high probability of meeting PS6 criteria for critical habitat, based on their suitability and size.

\section{Validation}

As demonstrated by Termansen (Termansen, McClean \& Preston 2006) and Lobo (Lobo, Jiménezvalverde \& Real 2008), measuring model accuracy solely from the often used "Area Under Curve" 
bioRxiv preprint doi: https://doi.org/10.1101/206763; this version posted October 20, 2017. The copyright holder for this preprint (which was not certified by peer review) is the author/funder, who has granted bioRxiv a license to display the preprint in perpetuity. It is made available under aCC-BY-ND 4.0 International license.

269 (AUC) values may be misleading. Therefore, to further validate our results, we used the "True Skill

270 Statistic" (TSS) (Allouche, Tsoar \& Kadmon 2006) and additionally also list the sensitivity and

271 specificity. These scores are based on the 30\% random test percentage of the species occurrence

272 samples. In addition the maps were validated during expert reviews conducted by the relevant

273 Wetlands International expert groups. 


\section{RESULTS}

\section{Overview}

276 A total of xxx species occurrence samples were collected and, after spatial filtering, 740 were used, with a minimum of 90 samples per species model (Table 2; Fig. 1). There were a limited number of samples in the east of the study site. The AUC score for all models was $>0.9$ and, importantly, the sensitivity, specificity and TSS scores were also good to very good (Table 3). A total of 1,767,749 $\mathrm{km}^{2}$ within the study area was identified as potential critical habitat from a total of 4,599,512 $\mathrm{km}^{2}$ identified as suitable habitat (Tables $1 \& 4$ ). $95 \%$ of the potential critical habitat and $96 \%$ of the other areas of suitable habitat were outside the boundaries of areas known to hold $1 \%$ of the species (Table 4; Figs $2 \& 3$ ).

\section{Anser albifrons}

As one of the most common geese in the Russian arctic, A. albifrons had a high number of occurrence records across most of its known range (Fig. 4a), although fewer occurrence points were available for the populations that occur east of the Taimyr. The model predicted suitable breeding habitat for large concentrations across much of the known breeding range (Wings Over Wetlands Project 2010) and 13 of the 15 known important areas for the species (Fig. 4b). The two areas that were not predicted to have suitable breeding habitat were in the far east of the study area. A total of 21 areas of potential critical habitat were identified, of which 11 overlapped with known critical habitat. Many of the newly identified areas were also between or adjacent to known critical habitat areas, such as along the coast of Baydaratskaya Guba, although 3 new areas were identified in Nova Zemblya.

\section{Anser erythropus}

295 A. erythropus had the fewest number of occurrence records (90) in the study. No occurrence points were available for the most easterly population known, which is located in Central and Eastern 
300

301

302

303

304

305

306

307

308

309

310

311

312

313

314

315

316

317

318

319

320

321

322

potential critical habitat, especially in the Yamal and Yugorskiy Peninsulas (Fig. 5b). Conversely, only one known key area in the Taimyr was identified as potential critical habitat, although the area predicted as suitable in the Taimyr closely matched the known breeding range.

\section{Branta bernicla}

This species breeds and moults close to the coast in the arctic tundra or islands (BirdLife 2015 XX2).

Fewer occurrence samples (116) were available for this species than most of the others studied, with most records spread across the central part of the species' breeding range (Fig. 6a). Areas between the eastern Taimyr and Lena Delta, Nova Zemblya, and the far west of the study area were underrepresented. Consequently, four of the most westerly sites, identified as known key areas, were not predicted as suitable, although these areas were peripheral or outside of the breeding range maps of the species (Fig. 6b) (Wings Over Wetlands Project 2010). In addition, three known important areas in the eastern part of the study area were not identified as suitable. However, nine areas were identified as new potential critical habitat in the islands to the far north, including Bolshevik Island, and a number of areas along the West Taimyr coast, up to the Yamal Peninsula.

\section{Branta ruficollis}

B. ruficollis has the smallest population size of the species studied (Table X) and its breeding range is restricted to areas in the Taimyr, Gydan and Yamal Peninsulas (BirdLife 2015 XX3). The species' distribution was modelled from 210 occurrence samples (Fig. 7a), mostly from the Taimyr, where an estimated $70 \%$ of the population breeds (BirdLife 2015 XX3). In total, 11 known key areas were not identified as potential critical habitat by the species model (Fig. 7b); however, many of these areas were outside or on the very edge of the reported breeding range of the species (Wings Over Wetlands Project 2010). In addition, large new areas were predicted as potential critical habitat within the breeding range, mainly located in the Taimyr and parts of the Yamal Peninsula.

\section{Cygnus columbianus bewickii}

Occurrence samples for this species were predominantly from the Western Siberia and North-

East/North-West Europe population, with far fewer samples from the Northern Siberia/Caspian and 
Asian populations (Wetlands International 2012), which breed in the Taimyr and to its east, up to the

Lena Delta (Fig. 8a). Consequently, known key areas in the eastern portion of the study area were not identified as potential critical habitat, even though large parts of the Lena Delta were identified as suitable habitat (Fig. 8b). The known key areas in the west were identified as potential critical habitat, with the exception of areas in the south of the Yamal Peninsula, which is on the periphery of the Western Siberia and North-East/North-West Europe population range (Wings Over Wetlands Project 2010). New potential critical habitat was also identified in the southern part of Nova

\section{DISCUSSION}

Identifying suitable habitat through species using modeling methods is a long-standing and verified approach (Ref.) and can provide a powerful tool particularly in regions that are remote and data poor. We used the MaxEnt model to identify suitable habitats for congregations of five Anatidae species to be used for risk assessment purposes. The results are in broad agreement with the known breeding ranges of the species. About $95 \%$ of the potential critical habitat identified was outside in congregatory Anatidae. As a result, it may be expected that for those species with currently depressed populations (as compared to higher historic populations), the areas that are currently being utilised are considerably smaller than the overall suitable habitat available for a species in this part of the arctic. Therefore, it may seem there are some cases in our study where the species' distributions may appear to have been overpredicted. For example, B. ruficollis has a known population of only 55,000 (Wetlands International 2015). However the species is unlikely to occupy 
351

352

353

354

355

356

357

358

359

360

361

362

363

364

365

366

367

368

369

370

371

372

presence of raptors (Prop \& Quinn 2003); however, this environmental variable was not included in this study, which may have influenced the results. Nevertheless, for a risk assessment the results are valuable to identify areas where the species may be present, especially as B. ruficollis is listed as a Vulnerable species on the IUCN Red List. In addition, for risk assessments it is arguably better to predict false positives, rather than false negatives.

Another reason for the mismatch may be that known critical habitat areas need further verification.

Our study has only focused occurrence data from the breeding and moulting seasons of these species. Extending this approach to other crucial life cycle stages, particularly the pre-breeding (northward) and post breeding (southward) migration periods, when birds may congregate and require different habitats across the breadth of the arctic should provide an important basis for initial risk assessments of potential developments in these areas too.

The accuracy of occurrence points is vital for the model results, and as many of the occurrence records used were based on telemetry data or highly accurate survey techniques, this should enable overall positive results. However there were large areas that were not predicted as suitable within the overall known breeding ranges of the species. This could be a result of small population sizes of species, as mentioned above, differences in the habitat preferences across their range or insufficient data (occurrence samples) in the particular areas. The latter reason could particularly have affected species occupying the eastern part of the study area, where occurrence records were scarce.

Following the IFC PS6 Guidance Notes, we attempted to identify habitat that was not only suitable for congregations of waterbirds or endangered species, but also critical. Converting species modelled suitability into critical habitat has no precedence in the scientific literature and our approach can be considered highly conservative. By identifying new critical habitat using the median area and average 
375 probability of habitat identified as suitable in known critical habitats, we automatically set a

376 threshold for potential critical habitat that would exclude half of the known critical habitat areas.

377 As a result, risk assessors should remain cautious of important areas that were not identified through

378 the modelling process. We advise that any area predicted to be suitable for each species is surveyed

379 in more detail, with particular attention to the areas predicted to be potentially critical.

380 While populations of bird species are known to vary over decades, nearly all five species are declining

381 due to changes and pressures in the arctic and along their entire migration cycles. Furthermore,

382 habitats across the arctic remains a highly dynamic state and are being greatly influenced by past and

383 ongoing natural and human induced changes within the region as well as elsewhere in the world. For

384 these reasons, the potential and likely critical habitats for these species and others may be expected

385 to change too. Over the medium term, identification of likely impacts and of mitigation options for

386 development activities will require periodic reassessments to be undertaken based on latest

387 information on species concentrations and habitat use preferences as well as environmental predictors. 


\section{ACKNOWLEDGEMENTS}

This research was carried out with the financial support of Royal Dutch Shell. The authors wish to

thank Leon Bennun and John Pilgrim (Biodiversity Consultancy), and Szabolcs Nagy (Wetlands

International) for their valuable and constructive inputs. This research would not have been possible without the International Wader Study Group (Arctic Birds Breeding Conditions Survey), Goose

Specialist Group, Swan Specialist Group and data contributors, or reviewers, including: Georg 
1. MaxEnt scripts and R scripts are included in Appendix S1.

2. MaxEnt model (5x)

3. GeoTIFF rasters probability $(5 x)$

4. Shapefiles

b. Potential Critical Habitat 


\section{REFERENCES}

Note - Duan, R., Kong, X., Huang, M., Fan, W. \& Wang, Z. (2014) appears incomplete

Add CAFF 2013, ABA.

(Arctic and Antarctic Research Institute). Protected areas map of Russia, http://oopt.aari.ru/oopt_map

(Birdlife International). Birdlife Data Zone, http://www.birdlife.org/datazone/site

(Ramsar Convention). Ramsar Sites Information Service, https://rsis.ramsar.org/

Alder, J. (2003) Putting the coast in the "Sea Around Us" project. , 1.

Allouche, O., Tsoar, A. \& Kadmon, R. (2006) Assessing the accuracy of species distribution models: Prevalence, kappa and the true skill statistic (TSS). Journal of Applied Ecology, 43, 1223-1232.

Arino, O., Ramos Perez, J.J., Kalogirou, V., Bontemps, S., Defourny, P. \& Van Bogaert, E. (2012) Global Land Cover Map for 2009 (GlobCover 2009).

Carroll, M.L., Townshend, J.R., DiMiceli, C.M., Noojipady, P. \& Sohlberg, R.A. (2009) A new global raster water mask at $250 \mathrm{~m}$ resolution. International Journal of Digital Earth, 2, 291-308.

Danielson, J.J. \& Gesch, D.B. (2011) Global Multi-Resolution Terrain Elevation Data 2010. Reston.

Duan, R., Kong, X., Huang, M., Fan, W. \& Wang, Z. (2014) The Predictive Performance and Stability of Six Species Distribution Models. , 9.

Edrén, S.M.C., Wisz, M.S., Teilmann, J., Dietz, R. \& Söderkvist, J. (2010) Modelling spatial patterns in harbour porpoise satellite telemetry data using maximum entropy. Ecography, 33, 698-708.

Elith, J., Graham, C.H., Anderson, R.P., Dudik, M., Ferrier, S., Guisan, a., Hijmans, R.J., Huettmann, F., Leathwick, J.R., Lehmann, a., Li, J., Lohmann, L.G., Loiselle, B. a., Manion, G., Moritz, C., Nakamura, M., Nakazawa, Y., Overton, J.M.C., Peterson, a. T., Phillips, S.J., Richardson, K., Scachetti-Pereira, R., Schapire, R.E., Soberon, J., Williams, S., Wisz, M.S. \& Zimmermann, N.E. (2006) Novel methods improve prediction of species' distributions from occurrence data. M. ECography, 29, 129-151.

Elith, J. \& Leathwick, J.R. (2009) Species Distribution Models: Ecological Explanation and Prediction Across Space and Time. Annual Review of Ecology, Evolution, and Systematics, 40, 677-697.

Elith, J., Phillips, S., Hastie, T., Dud, M., Chee, Y.E., Yates, C., Avenue, P., Park, F., York, N. \& Division, S. (2011) A statistical explanation of MaxEnt for ecologists. Environment, 1-28.

Fourcade, Y., Engler, J.O., Rödder, D. \& Secondi, J. (2014) Mapping species distributions with MAXENT using a geographically biased sample of presence data: A performance assessment of methods for correcting sampling bias. PLOS ONE, 9.

Hengl, T., de Jesus, J.M., MacMillan, R.A., Batjes, N.H., Heuvelink, G.B.M., Ribeiro, E., Samuel-Rosa, A., Kempen, B., Leenaars, J.G.B., Walsh, M.G. \& Gonzalez, M.R. (2014) SoilGrids1km--global soil information based on automated mapping. PloS one, 9, e105992.

Hijmans, R.J., Cameron, S.E., Parra, J.L., Jones, P.G. \& Jarvis, A. (2005) Very high resolution interpolated climate surfaces for global land areas. International Journal of Climatology, 25, 1965-1978.

IFC. (2012a) Performance Standard 6: Biodiversity Conservation and Sustainable Management of Living Natural Resources. , 7.

IFC. (2012b) Guidance Note 6 Biodiversity Conservation and Sustainable Management of Living Natural Resources. , 1-70.

Jakobsson, M., Mayer, L., Coakley, B., Dowdeswell, J.A., Forbes, S., Fridman, B., Hodnesdal, H., 
Noormets, R., Pedersen, R., Rebesco, M., Schenke, H.W., Zarayskaya, Y., Accettella, D., Armstrong, A., Anderson, R.M., Bienhoff, P., Camerlenghi, A., Chruch, I., Edwards, M., Gardner, J. V, Hall, J.K., Hell, B., Hestvik, O., Kristoffersen, Y., Marcussen, C., Mohammad, R., Mosher, D., Nghiem, S. V, Pedrosa, M.T., G, T.P. \& Weatherall, P. (2012) The International Bathymetric Chart of the Arctic Ocean (IBCAO) Version 3.0. Geophysical Research Letters, 39.

Krivenko, V.G. (2000) Wetlands in Russia, Volume 3: Wetlands on the Ramsar Shadow List (eds V.E. Flint, V.Y. Iliashenko, I.E. Kamennova, L.B. Kholopova, A.L. Mischenko, V.A. Orlov, \& V.G. Vinogradov). Wetlands International.

Lehner, B. \& Grill, G. (2013) Global river hydrography and network routing: baseline data and new approaches to study the world's large river systems. Hydrological Processes, 27, 2171-2186.

Lobo, J.M., Jiménez-valverde, A. \& Real, R. (2008) AUC: A misleading measure of the performance of predictive distribution models. Global Ecology and Biogeography, 17, 145-151.

Martin, C.S., Tolley, M.J., Farmer, L.E., McOwen, C., Geffert, J.L., Scharlemann, J.P.W., Thomas, H.L., van Bochove, J.H., Stanwell-Smith, D., Hutton, J.M., Lascelles, B., Pilgrim, J.D., Ekstrom, J.M.M. \& Tittensor, D.P. (2015) A global map to aid the identification and screening of Critical Habitat for marine industries. in Prep, 53, 45-53.

Phillips, S.J. \& Dudik, M. (2008) Modeling of species distributions with MaxEnt: new extensions and a comprehensive evaluation. Ecography, 31, 161-175.

Phillips, S.J., Dudík, M., Elith, J., Graham, C.H., Lehmann, A., Leathwick, J. \& Ferrier, S. (2009) Sample selection bias and presence-only distribution models: Implications for background and pseudoabsence data. Ecological Applications, 19, 181-197.

Phillips, S., Dudík, M. \& Schapire, R. (2004) A maximum entropy approach to species distribution modeling. Proceedings of the twenty-first ..., 655-662.

Termansen, M., McClean, C.J. \& Preston, C.D. (2006) The use of genetic algorithms and Bayesian classification to model species distributions. Ecological Modelling, 192, 410-424.

The IUCN Red List of Threatened Species. http://www.iucnredlist.org/

Wings Over Wetlands. (2011) Conservation of Internationally Important Sites for Waterbirds in the African-Eurasian Waterbird Agreement Area.

Wohl, K.D. (U. S.F. and W.S. (2006) The Arctic - origin of flyways. Waterbirds around the world (eds G.. Boere, C.A. Galbraith, \& D.A. Stroud), p. The Stationary Office, Edinburgh.

STILL TO DO in Mendeley: REFS FOR RESULTS and OCCURRENCE POINTS (abbcs, gbif, individual telemetry studies)

Wings Over Wetlands Project (2010) Critical Site Network Tool. UNEP-WCMC, BirdLife International and Wetlands International, Cambridge, UK and Wageningen, The Netherlands

(BirdLife 2015 XX1) = BirdLife International (2015) Species factsheet: Anser erythropus. Downloaded from http://www. birdlife.org on 23/11/2015. Recommended citation for factsheets for more than one species: BirdLife International (2015) IUCN Red List for birds. Downloaded from http://www.birdlife.org on 23/11/2015.

(BirdLife 2015 XX2) = BirdLife International (2015) Species factsheet: Branta bernicla. Downloaded from http://www.birdlife.org on 23/11/2015. Recommended citation for 
501 factsheets for more than one species: BirdLife International (2015) IUCN Red List for birds.

502 Downloaded from http://www.birdlife.org on 23/11/2015.

503 "Waterbird Population Estimates". Retrieved from wpe.wetlands.org on Monday 23 Nov 2015

504 (BirdLife 2015 XX3) BirdLife International (2015) Species factsheet: Branta ruficollis.

505 Downloaded from http://www.birdlife.org on 23/11/2015. Recommended citation for

506 factsheets for more than one species: BirdLife International (2015) IUCN Red List for birds.

507 Downloaded from http://www.birdlife.org on 23/11/2015.

508

509

510

511

512

513

514

515

516

517

518

519

520

521

522

523

524

525

526

527

Prop, J \& Quinn J.L (2003) Constrained by available raptor hosts and islands: density-dependent reproductive success in red-breasted geese. Oikos, 102, 571-580.

Cranswick, P.A., Raducescu, L., Hilton G.M. \& Petkov, N. 2012. International Single Species Action Plan for the Conservation of the Red-breasted Goose (Branta ruficollis). AEWA Technical Series No. 46.

Vangeluwe D., Rozenfeld S. B., Dmitriev A. E., Bulteau V. 2012. Preliminary results from GPS tracking of Red-Breasted Geese (Branta ruficollis) from their Gydan peninsula (Russia) breeding grounds. Casarca, 15(2): 80-93.

Jones, T., Martin, K., Barov, B., Nagy, S. (Compilers). 2008. International Single Species Action Plan for the Conservation of the Western Palearctic Population of the Lesser White-fronted Goose Anser erythropus. AEWA Technical Series No.36. Bonn, Germany.

Kokorev Y., Quinn J. L. 1999. Geese in the Pura Basin, Taimyr: their status, trends and the effects of the lemming cycle on breeding parameters. Casarca, 5: 272-295.

Kostin I. O., Mooij J. H. 1995. Influence of weather conditions and other factors on the reproductive cycle of the Red-breasted Geese Branta ruficollis on the Taymir Peninsula. - Wildfowl, 46: 45-54. 
Table 1. Classification and justification of critical habitat based on IFC PS6

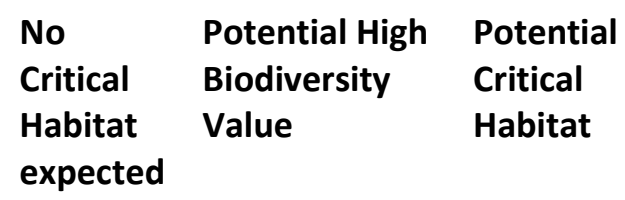

\section{Likely Critical}

Habitat

expected

\begin{tabular}{|c|c|c|c|c|}
\hline $\begin{array}{l}\text { Criterion } 1 \\
\text { and } 3 \\
\text { Critically } \\
\text { Endangered } \\
\text { (CR) species }\end{array}$ & $\begin{array}{l}\text { Not } \\
\text { expected } \\
\text { to be } \\
\text { suitable }\end{array}$ & Not applicable & $\begin{array}{l}\text { Area } \\
\text { expected to } \\
\text { regularly } \\
\text { sustain } \geq 1 \\
\text { individual, } \\
\text { based on } \\
\text { MaxEnt } \\
\text { modelling }\end{array}$ & $\begin{array}{l}\text { Area with } \\
\text { known } \\
\text { regular } \\
\text { occurrence of } \\
\geq 1 \text { individual }\end{array}$ \\
\hline $\begin{array}{l}\text { Criterion } 1 \\
\text { and } 3 \\
\text { Endangered } \\
\text { (EN) } \\
\text { species }\end{array}$ & $\begin{array}{l}\text { Not } \\
\text { expected } \\
\text { to be } \\
\text { suitable }\end{array}$ & $\begin{array}{l}\text { Area expected } \\
\text { to be suitable } \\
\text { based on } \\
\text { MaxEnt } \\
\text { modelling }\end{array}$ & $\begin{array}{l}\text { Area } \\
\text { expected to } \\
\text { regularly } \\
\text { sustain } \geq 1 \% \\
\text { of the } \\
\text { biogeographic } \\
\text { population, } \\
\text { based on } \\
\text { MaxEnt } \\
\text { modelling }\end{array}$ & $\begin{array}{l}\text { Area known } \\
\text { to regularly } \\
\text { sustain } \geq 1 \% \\
\text { of the } \\
\text { biogeographic } \\
\text { population }\end{array}$ \\
\hline $\begin{array}{l}\text { Criterion } 3 \\
\text { Vulnerable } \\
\text { (VU) } \\
\text { Near } \\
\text { Threatened } \\
\text { (NT) } \\
\text { Least } \\
\text { Concern } \\
\text { (LC) }\end{array}$ & $\begin{array}{l}\text { Suitable } \\
\text { habitat }\end{array}$ & $\begin{array}{l}\text { Area expected } \\
\text { to be suitable } \\
\text { during life } \\
\text { cycle stages } \\
\text { where species } \\
\text { is likely to } \\
\text { occur in } \\
\text { concentrations } \\
\text { of } \geq 1 \% \text { of the } \\
\text { biogeographic } \\
\text { concentration, } \\
\text { or } \geq 20,000 \\
\text { individuals, } \\
\text { based on } \\
\text { MaxEnt } \\
\text { modelling }\end{array}$ & $\begin{array}{l}\text { Area } \\
\text { expected to } \\
\text { regularly } \\
\text { sustain } \geq 1 \% \\
\text { of the } \\
\text { biogeographic } \\
\text { population, or } \\
\geq 20,000 \\
\text { individuals, } \\
\text { based on } \\
\text { MaxEnt } \\
\text { modelling }\end{array}$ & $\begin{array}{l}\text { Area known } \\
\text { to regularly } \\
\text { sustain } \geq 1 \% \\
\text { of the } \\
\text { biogeographic } \\
\text { population, or } \\
\geq 20,000 \\
\text { individuals }\end{array}$ \\
\hline
\end{tabular}


bioRxiv preprint doi: https://doi.org/10 1101/206763; this version posted October 20, 2017. The copyright holder for this preprint (which was not certified by peer review) is the author/funder, who has granted bioRxiv a license to display the preprint in perpetuity. It is made available under aCC-BY-ND 4.0 International license.

533 Table 2. Occurrence samples of each species used

\begin{tabular}{lll}
\hline Species & \# occurrence samples & $\mathbf{1 \%}$ area \\
\hline $\begin{array}{l}\text { Anser albifrons } \\
\text { (Greater White-fronted Goose) }\end{array}$ & 176 & 1,672 \\
$\begin{array}{l}\text { Anser erythropus } \\
\text { (Lesser White-fronted Goose) }\end{array}$ & 90 & 499 \\
$\begin{array}{l}\text { Branta bernicla } \\
\text { (Brent Goose) } \\
\text { Branta ruficollis } \\
\text { (Red-breasted Goose) }\end{array}$ & 116 & 390 \\
$\begin{array}{l}\text { Cygnus columbianus } \\
\text { (Tundra Swan) }\end{array}$ & 210 & 749 \\
\hline
\end{tabular}

534

535 
Table 2. Overview of species and occurrence samples used

\begin{tabular}{|c|c|c|c|c|c|}
\hline Species & $\begin{array}{l}\text { IUCN Conservation } \\
\text { Status }^{1}\end{array}$ & $\begin{array}{l}\text { Population } \\
\text { Estimate }^{2}\end{array}$ & $\begin{array}{l}\text { \# tracked } \\
\text { individuals }\end{array}$ & $\begin{array}{l}\text { \# occurrence } \\
\text { samples }\end{array}$ & $1 \%$ area \\
\hline $\begin{array}{l}\text { Anser } \\
\text { albifrons } \\
\text { (Greater } \\
\text { White- } \\
\text { fronted } \\
\text { Goose) }\end{array}$ & Least Concern (LC) & & & 176 & 1,672 \\
\hline $\begin{array}{l}\text { Anser } \\
\text { erythropus } \\
\text { (Lesser White- } \\
\text { fronted } \\
\text { Goose) }\end{array}$ & $\begin{array}{l}\text { Vulnerable (VU) } \\
\text { Although the } \\
\text { population in } \\
\text { question is } \\
\text { considered } \\
\text { threatened and has } \\
\text { been included } \\
\text { under AEWA }\end{array}$ & & & 90 & 499 \\
\hline $\begin{array}{l}\text { Branta } \\
\text { bernicla } \\
\text { (Brent Goose) }\end{array}$ & & & & 116 & 390 \\
\hline $\begin{array}{l}\text { Branta } \\
\text { ruficollis } \\
\text { (Red-breasted } \\
\text { Goose) }\end{array}$ & VU & & & 210 & 749 \\
\hline $\begin{array}{l}\text { Cygnus } \\
\text { columbianus } \\
\text { bewickii } \\
\text { (Tundra } \\
\text { Swan) }\end{array}$ & $\begin{array}{l}\text { LC. Although the } \\
\text { population is } \\
\text { considered } \\
\text { threatened and has } \\
\text { been included } \\
\text { under AEWA Action } \\
\text { Plan }\end{array}$ & & & 148 & 623 \\
\hline
\end{tabular}

$538 \quad{ }^{2}$ Wetlands International (2012)

540 Table 3. Validation of the MaxEnt models

\begin{tabular}{lllll}
\hline Species & AUCt & Sensitivity & Specificity & TSS \\
\hline $\begin{array}{l}\text { Anser albifrons } \\
\text { (Greater White- } \\
\text { fronted Goose) }\end{array}$ & 0.973 & 0.86 & 0.93 & 0.79 \\
$\begin{array}{l}\text { Anser erythropus } \\
\text { (Lesser White- }\end{array}$ & 0.960 & 0.86 & 0.90 & 0.76 \\
$\begin{array}{l}\text { fronted Goose) } \\
\text { Branta bernicla } \\
\text { (Brent Goose) }\end{array}$ & 0.993 & 0.91 & 0.98 & 0.91 \\
$\begin{array}{l}\text { Branta ruficollis } \\
\text { (Red-breasted }\end{array}$ & 0.968 & 0.85 & 0.92 & 0.78 \\
$\begin{array}{l}\text { Goose) } \\
\text { Cygnus columbianus } \\
\text { bewickii } \\
\text { (Bewick's Swan) }\end{array}$ & 0.983 & 0.88 & 0.92 & 0.85 \\
\hline
\end{tabular}

541

†Area under curve; ¥ True Skill Statistic 
543 Table 4. Potential high biodiversity value (HBV) and potential critical habitat

544 (PCH) per species, and the fractions in known important areas (KIA)

\begin{tabular}{|c|c|c|c|c|c|c|c|}
\hline Species & \# KIA & $\mathrm{PCH}\left(\mathrm{km}^{2}\right)$ & HBV $\left(\mathrm{km}^{2}\right)$ & $\begin{array}{l}\text { PCH outside } \\
\text { KIA km } \text { km }^{2} \%\end{array}$ & $\begin{array}{l}\text { HBV outside } \\
\text { KIA } \text { km }^{2}(\%)\end{array}$ & $\begin{array}{l}\text { KIA with } \\
\text { PCH \# (\%) }\end{array}$ & $\begin{array}{l}\text { KIA with } \\
\text { HBV \# (\%) }\end{array}$ \\
\hline $\begin{array}{l}\text { Anser albifrons } \\
\text { (Greater } \\
\text { White-fronted } \\
\text { Goose) }\end{array}$ & 15 & 164,635 & $1,235,684$ & $\begin{array}{l}144,478 \\
(88 \%)\end{array}$ & $\begin{array}{l}1,156,328 \\
(94 \%)\end{array}$ & $\begin{array}{l}4 \\
(27 \%)\end{array}$ & $\begin{array}{l}13 \\
(87 \%)\end{array}$ \\
\hline $\begin{array}{l}\text { Anser } \\
\text { erythropus } \\
\text { (Lesser White- } \\
\text { fronted Goose) }\end{array}$ & 11 & 457,225 & 916,111 & $\begin{array}{l}445,888 \\
(98 \%)\end{array}$ & $\begin{array}{l}893,747 \\
(98 \%)\end{array}$ & $\begin{array}{l}5 \\
(45 \%)\end{array}$ & $\begin{array}{l}8 \\
(73 \%)\end{array}$ \\
\hline $\begin{array}{l}\text { Branta bernicla } \\
\text { (Brent Goose) }\end{array}$ & 10 & 223,979 & 385,941 & $\begin{array}{l}221,811 \\
(99 \%)\end{array}$ & $\begin{array}{l}377,015 \\
(98 \%)\end{array}$ & $\begin{array}{l}2 \\
(20 \%)\end{array}$ & $\begin{array}{l}5 \\
(50 \%)\end{array}$ \\
\hline $\begin{array}{l}\text { Branta } \\
\text { ruficollis } \\
\text { (Red-breasted } \\
\text { Goose) }\end{array}$ & 13 & 533,249 & $1,162,723$ & $\begin{array}{l}516,439 \\
(97 \%)\end{array}$ & $\begin{array}{l}1,123,013 \\
(97 \%)\end{array}$ & $\begin{array}{l}4 \\
(31 \%)\end{array}$ & $\begin{array}{l}9 \\
(69 \%)\end{array}$ \\
\hline $\begin{array}{l}\text { Cygnus } \\
\text { columbianus } \\
\text { (Tundra Swan) }\end{array}$ & 11 & 135,217 & 958,341 & $\begin{array}{l}115,843 \\
(86 \%)\end{array}$ & $\begin{array}{l}908,903 \\
(95 \%)\end{array}$ & $\begin{array}{l}3 \\
(27 \%)\end{array}$ & $\begin{array}{l}10 \\
(91 \%)\end{array}$ \\
\hline $\begin{array}{l}\text { Total distinct } \\
\text { area }\end{array}$ & & $1,767,749$ & $4,599,512$ & $\begin{array}{l}1,674,434 \\
(95 \%)\end{array}$ & $\begin{array}{l}4,419,112 \\
(96 \%)\end{array}$ & & \\
\hline
\end{tabular}


bioRxiv preprint doi: https://doi.org/10.1101/206763; this version posted October 20, 2017. The copyright holder for this preprint (which was not certified by peer review) is the author/funder, who has granted bioRxiv a license to display the preprint in perpetuity. It is made available under aCC-BY-ND 4.0 International license.

$548 \quad$ Fig. 1 Distribution of waterbird occurrence samples used (black dots) 
bioRxiv preprint doi: https://doi.org/101101/206763; this version posted October 20, 2017. The copyright holder for this preprint (which was not certified by peer review) is the author/funder, who has granted bioRxiv a license to display the preprint in perpetuity. It is made available under aCC-BY-ND 4.0 International license.

551 Fig. 2. Suitable habitat (dashed) and potential critical habitat (black) during the 552 breeding season for all five species

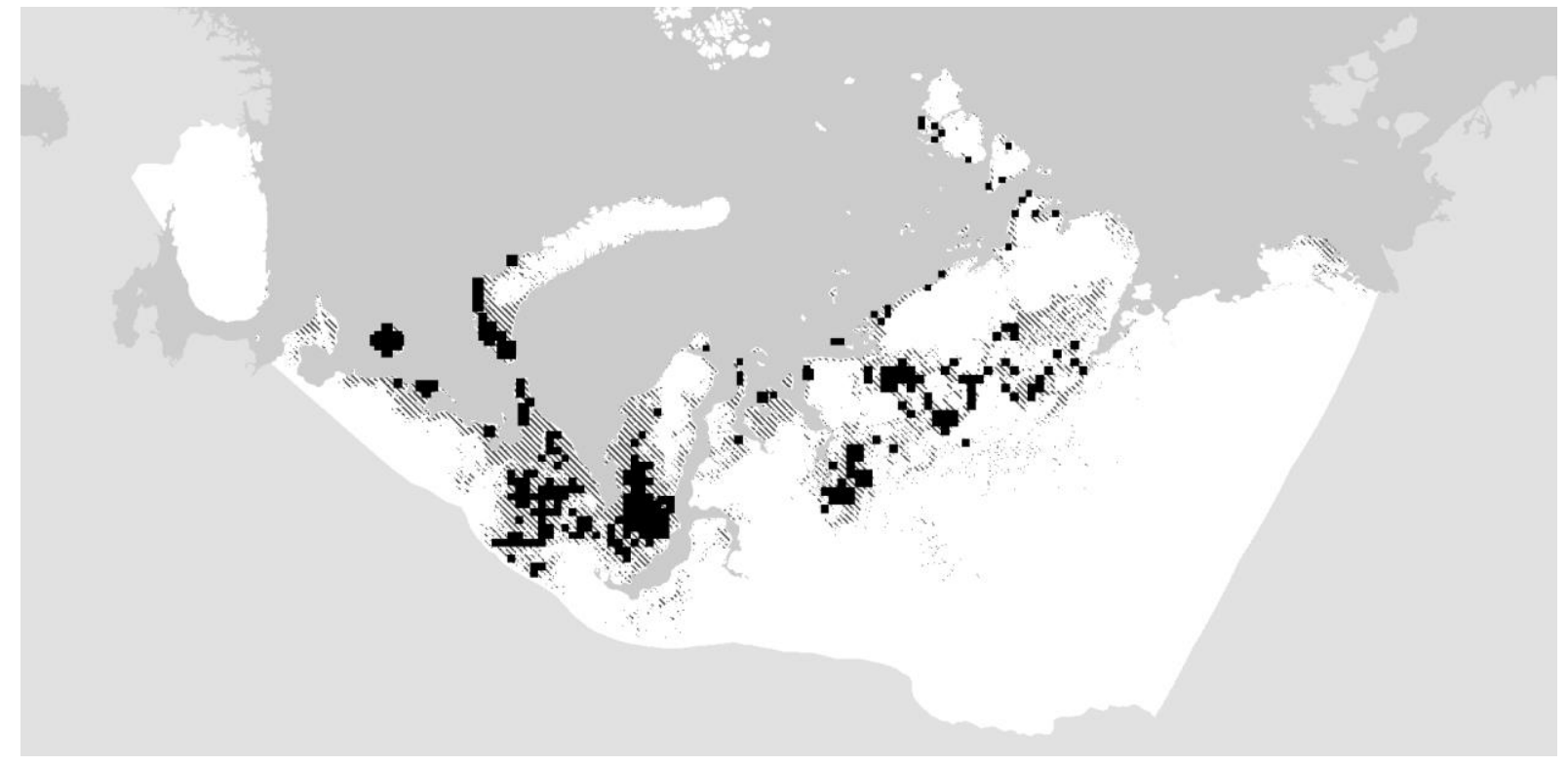


bioRxiv preprint doi: https://doi.org/10.1101/206763; this version posted October 20, 2017. The copyright holder for this preprint (which was not certified by peer review) is the author/funder, who has granted bioRxiv a license to display the preprint in perpetuity. It is made available under aCC-BY-ND 4.0 International license.

555

Fig. 3. Known important areas for all species

556 
bioRxiv preprint doi: https://doi org/10.1101/206763. this version posted October 20, 2017. The copyright holder for this preprint (which was not certified by peer review) is the author/funder, who has granted bioRxiv a license to display the preprint in perpetuity. It is made available under aCC-BY-ND 4.0 International license.

$557 \quad$ Fig. 4. Anser albifrons (a) identified suitable habitat, and (b) likely (dashed) and 558 potential critical habitat (black)

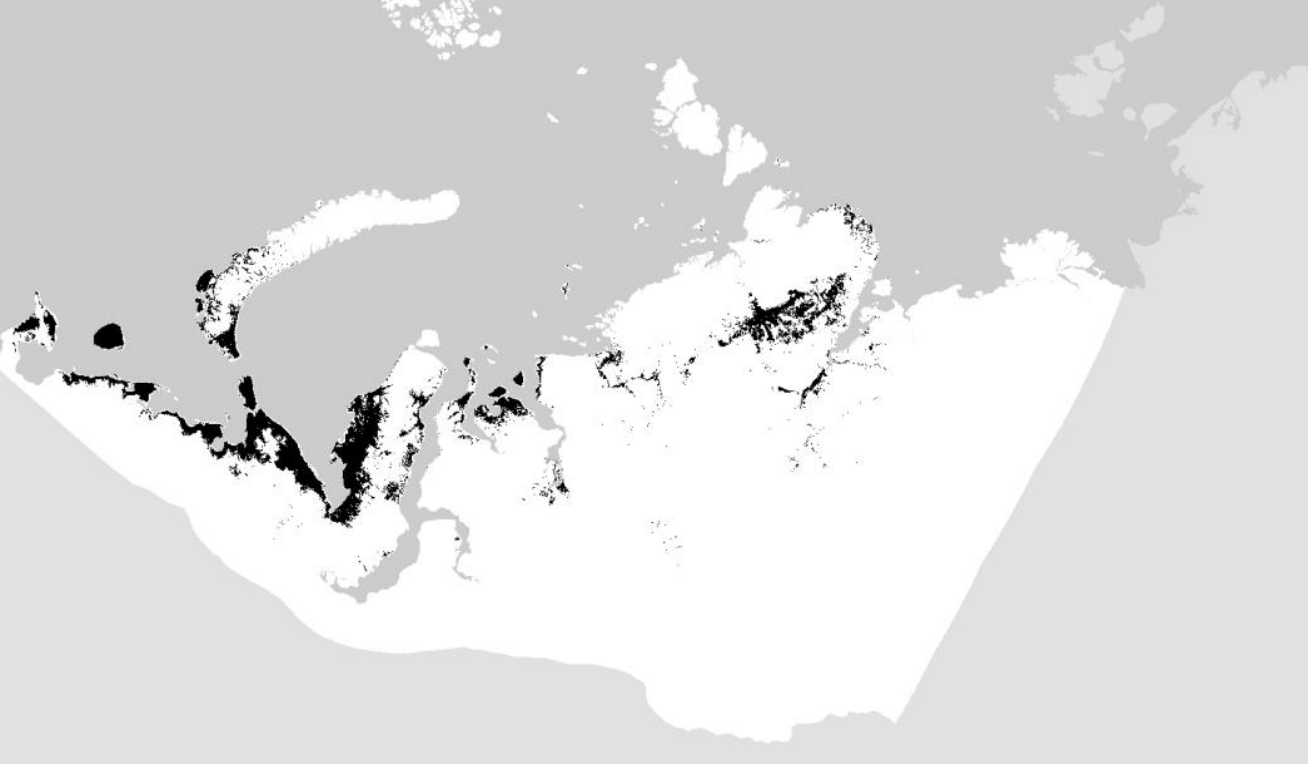


bioRxiv preprint doi: https://doi org/10 1101/206763. this version posted October 20, 2017. The copyright holder for this preprint (which was not certified by peer review) is the author/funder, who has granted bioRxiv a license to display the preprint in perpetuity. It is made available under aCC-BY-ND 4.0 International license.

561 Fig. 5. Anser erythropus (a) identified suitable habitat, and (b) likely (dashed) and 562 potential critical habitat (black)
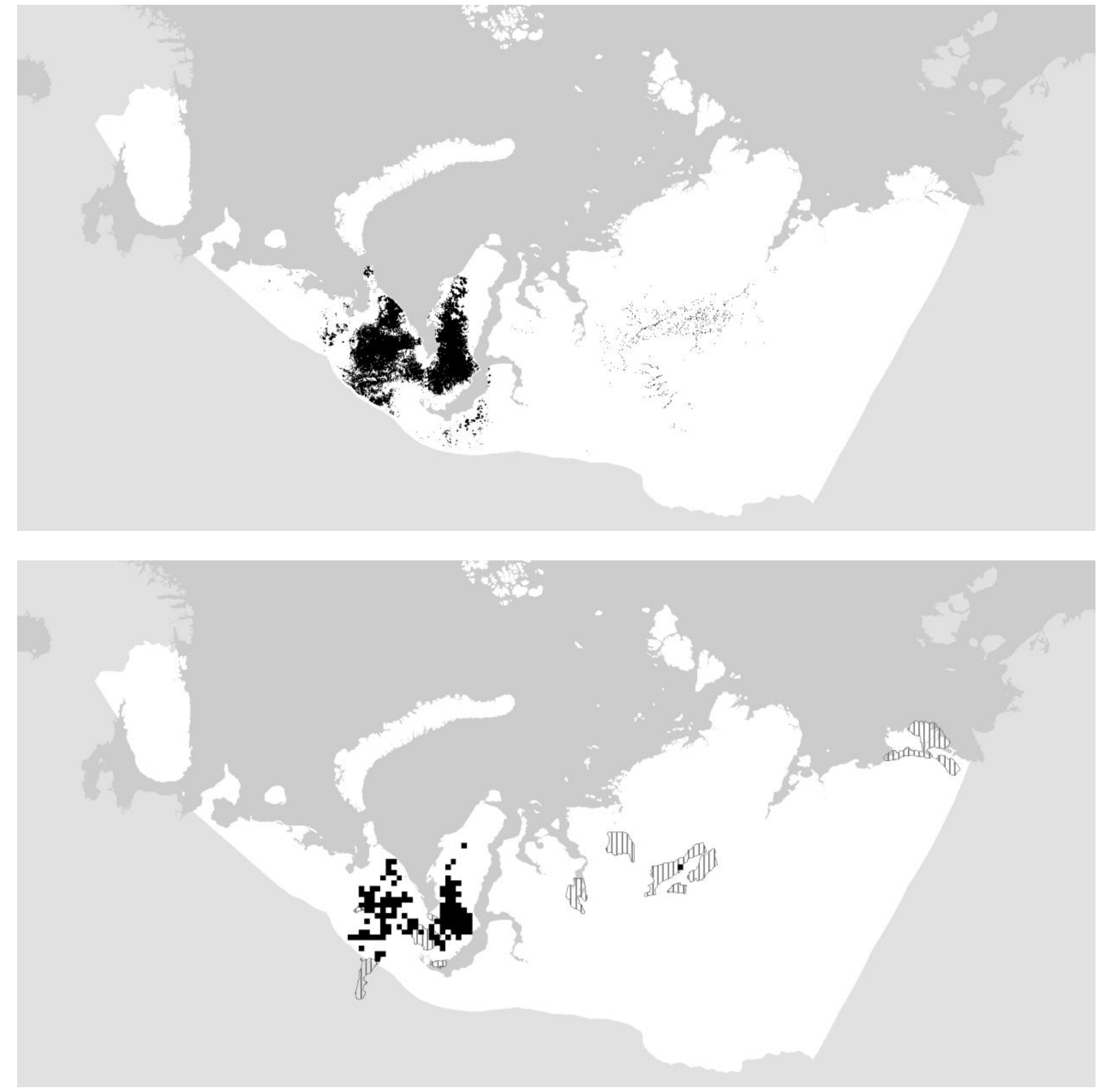
bioRxiv preprint doi: https://doi.org/10.1101/206763; this version posted October 20, 2017. The copyright holder for this preprint (which was not certified by peer review) is the author/funder, who has granted bioRxiv a license to display the preprint in perpetuity. It is made available under aCC-BY-ND 4.0 International license.

565 Fig. 6. Branta bernicla (a) identified suitable habitat, and (b) likely (dashed) and 566 potential critical habitat (black)

567

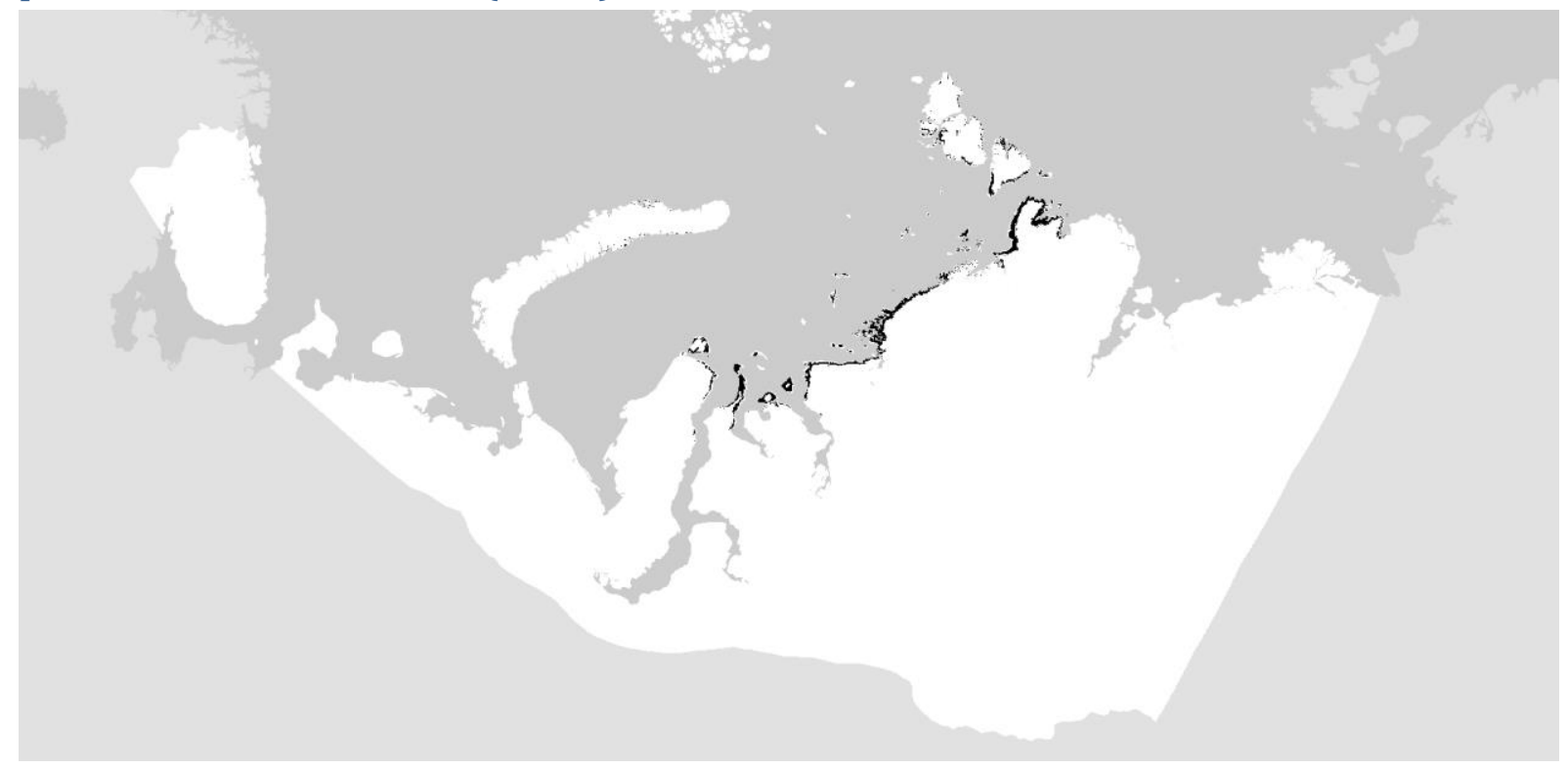


bioRxiv preprint doi: https://doi org/10.1101/206763. this version posted October 20, 2017. The copyright holder for this preprint (which was not certified by peer review) is the author/funder, who has granted bioRxiv a license to display the preprint in perpetuity. It is made available under aCC-BY-ND 4.0 International license.

569 Fig. 7. Branta ruficollis (a) identified suitable habitat, and (b) likely (dashed) and 570 potential critical habitat (black)

571 
bioRxiv preprint doi: https://doi org/10 1101/206763. this version posted October 20, 2017. The copyright holder for this preprint (which was not certified by peer review) is the author/funder, who has granted bioRxiv a license to display the preprint in perpetuity. It is made available under aCC-BY-ND 4.0 International license.

573 Fig. 8. Cygnus columbianus (a) identified suitable habitat, and (b) likely (dashed)

574 and potential critical habitat (black)

575

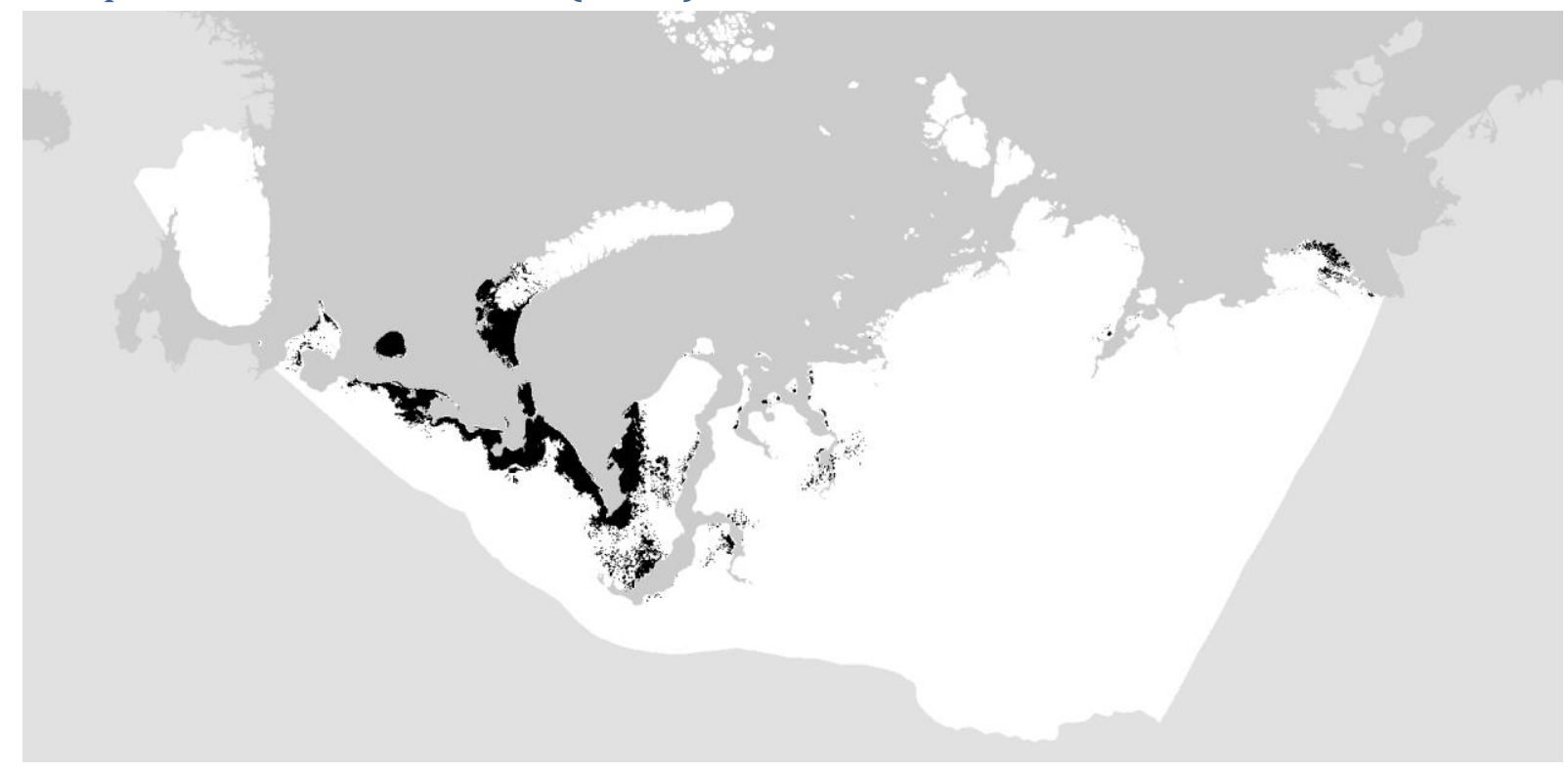




\section{SUPPORTING INFORMATION}

578 Additional Supporting Information may be found in the online version of this article:

579 Appendix S1. MaxEnt scripts and R commands used

580 Appendix S2. Supplementary tables

581

Table S1. Environmental predictors used in MaxEnt

582

Table S2. Matrix of the Spearman's correlation coefficients between the environmental

583 layers

584

Table S3. The environmental predictors used for each model

585

Appendix S3. Supplementary figures

586

Figure S1. Methodology overview

587 


\section{MaxEnt script to extract random background points:}

590

D:\MaxEnt\EnvLayersFinal>java -cp D:\MaxEnt\maxent.jar density.tools.RandomSample 100000

591

bioclim01.asc bioclim02.asc bioclim03.asc bioclim04.asc bioclim05.asc bioclim06.asc bioclim07.asc

592

bioclim08.asc bioclim09.asc bioclim10.asc bioclim11.asc bioclim12.asc bioclim13.asc bioclim14.asc

593

bioclim15.asc bioclim16.asc bioclim17.asc bioclim18.asc bioclim19.asc dist2coast.asc dist2estuary.asc

594

dist2freshwater.asc dist2mudflat.asc elevation.asc elevation_aspect.asc elevation_slope.asc

595

elevation_std.asc globcover2009_v2.3.asc soilgwrb_freshw.asc > 100krandomsample.swd

596

597

598

599

600

601

602

603

604

605

606

607

608

609

610

611

FMNH

612

abbcs

NOF

ZMO

\section{CLO}

DN

\section{R commands for Spearman's ranked correlations:}

sample $=$ read.csv $($ file.choose (), header $=\mathrm{T})$

coefficients $=$ cor(sample, method $=$ "spearman")

write.csv(coefficients, file="coefficients.csv")

\section{Occurrence data sources}

\section{AEWA report Yamalo-Nenetsky Autonomous Okrug}

telemetry

ArtDatabanken

BioFokus

BirdlifeFinland

iNaturalist 
bioRxiv preprint doi: https://doi.org/10.1101/206763; this version posted October 20, 2017. The copyright holder for this preprint (which was not certified by peer review) is the author/funder, who has granted bioRxiv a license to display the preprint in perpetuity. It is made available under aCC-BY-ND 4.0 International license.

$613 \mathrm{MFU}$

614 Miljøfaglig Utredning

615 naturgucker

616 NRM

617 miljolare

618 gbif

619 Kolguev

620 Mindaugas Dagys 
Table S1. Overview of environmental predictors

\begin{tabular}{|c|c|c|}
\hline Predictor code & Description & Reference \\
\hline \multicolumn{2}{|l|}{ BioClimatic variables } & \multirow[t]{20}{*}{ (Hijmans et al. 2005) } \\
\hline Bioclim01 & Annual Mean Temperature & \\
\hline Bioclim02 & Mean Diurnal Range (Mean monthly (max temp - min temp)) & \\
\hline Bioclim03 & Isothermality (BIO2/BIO7) (* 100) & \\
\hline Bioclim04 & Temperature Seasonality (standard deviation *100) & \\
\hline Bioclim05 & Max Temperature of Warmest Month & \\
\hline Bioclim06 & Min Temperature of Coldest Month & \\
\hline Bioclim07 & Temperature Annual Range (BIO5-BIO6) & \\
\hline Bioclim08 & Mean Temperature of Wettest Quarter & \\
\hline Bioclim09 & Mean Temperature of Driest Quarter & \\
\hline Bioclim10 & Mean Temperature of Warmest Quarter & \\
\hline Bioclim11 & Mean Temperature of Coldest Quarter & \\
\hline Bioclim12 & Annual Precipitation & \\
\hline Bioclim13 & Precipitation of Wettest Month & \\
\hline Bioclim14 & Precipitation of Driest Month & \\
\hline Bioclim15 & Precipitation Seasonality (Coefficient of Variation) & \\
\hline Bioclim16 & Precipitation of Wettest Quarter & \\
\hline Bioclim17 & Precipitation of Driest Quarter & \\
\hline Bioclim18 & Precipitation of Warmest Quarter & \\
\hline Bioclim19 & Precipitation of Coldest Quarter & \\
\hline \multicolumn{2}{|l|}{ Euclidian distances } & \multirow[t]{5}{*}{ Derived } \\
\hline Dist2coast & Distance to nearest coast & \\
\hline Dist2estuary & Distance to nearest estuary & \\
\hline Dist2freshwater & Distance to nearest freshwater body & \\
\hline Dist2shallowflatcoast & Distance to shallow coastal flats & \\
\hline \multicolumn{3}{|l|}{$\begin{array}{r}\text { Elevation and elevation- } \\
\text { derived }\end{array}$} \\
\hline Elevation & Elevation from Bioclimatic variable & (Hijmans et al. 2005) \\
\hline Elevation_slope & Elevation slope & Derived \\
\hline Elevation_std & Elevation standard deviation & $\begin{array}{l}\text { (Danielson \& Gesch } \\
\text { 2011) }\end{array}$ \\
\hline \multicolumn{3}{|l|}{ Others } \\
\hline GlobCover2009_v2.3 & Global Landcover & (Arino et al. 2012) \\
\hline Soilgwrb_freshw & Dominant soiltype & Derived \\
\hline
\end{tabular}




\section{bioRxiv preprint doi: hittps:///doi.org/10.1101/206763; this version posted October 20, 2017. The copyright holder for this preprint (which
was not certified by peer review) is the authorffunder, who has granted bioRxiv alicense to display the preprint in perpetuity. It is made}

623 Table S2. Pairwise correlations of environmental layers 
bioRxiv preprint doi: https://doi. org/10 1101/206763: this version posted October 20, 2017. The copyright holder for this preprint (which was not certified by peer review) is the author/funder, who has granted bioRxiv a license to display the preprint in perpetuity. It is made available under aCC-BY-ND 4.0 International license.

624 Appendix S3. Supplementary figures

625 Fig. S1. Overview of the method used to create the critical habitat maps

626

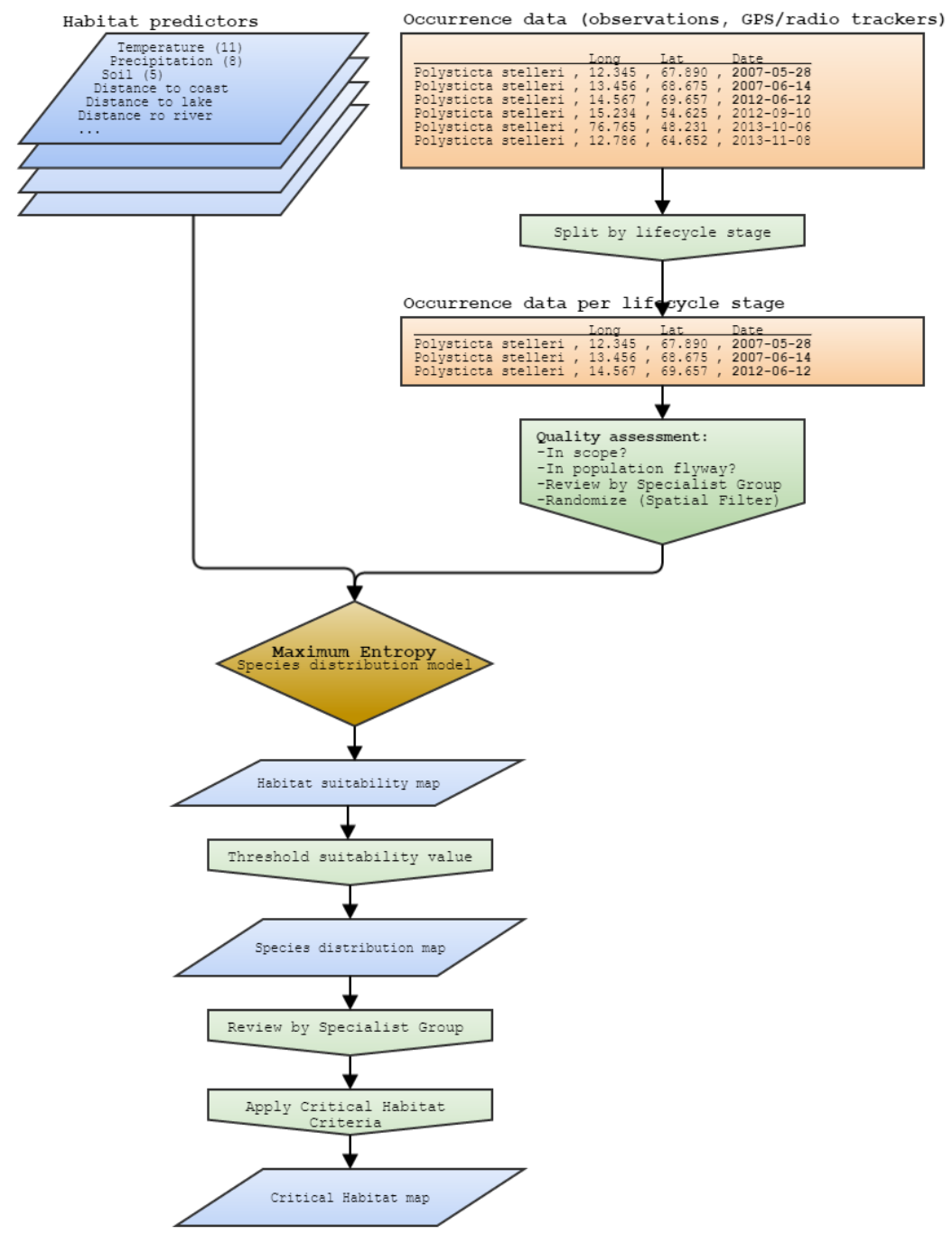

627 
bioRxiv preprint doi: https://doi.org/10.1101/206763; this version posted October 20, 2017. The copyright holder for this preprint (which was not certified by peer review) is the author/funder, who has granted bioRxiv a license to display the preprint in perpetuity. It is made available under aCC-BY-ND 4.0 International license. 